\title{
'Julle noem My Leermeester ... en julle is reg, want Ek is dit' (Joh 13:13). Onderrig in die Evangelie van Johannes ${ }^{1}$
}

\author{
Van der Watt, Jan \\ Universiteit van die Vrystaat \\ janvanderwatt@kpnmail.nl
}

\begin{abstract}
Teaching in John's Gospel

In this article the significance is analysed of the Johannine concept of teaching and related themes, like teachers, different ways of teaching, both formal and informal. Both terminological as well as conceptual references to teaching are considered. It is shown that the teaching of Jesus to his followers is described in terms of Jewish rabbinic activities and that social conventions in this respect are honoured. However, when the Father teaches Jesus, the metaphor changes to typical Jewish teaching within a family context where the father teaches his child through example. The child observes what the father says and mimes these actions and words. This ensures that the teaching of Jesus corresponds to that of the Father. When Jesus goes back to his Father, the Paraclete continues this educational process by reminding and guiding the followers of the words of Jesus. The Gospel however refrains from describing the followers of Jesus as teachers, but calls them witnesses to the teaching of Jesus - the teaching remains that of Jesus. This concept is so central to the theology of John that the theological structure would collapse if it would be ignored or downplayed.
\end{abstract}

Keywords

Teacher, Teaching in John's Gospel, Rabbi in John's Gospel

1 Hierdie artikel word ter nagedagtenis aan Maarten Menken, 'n mede-Johannesnavorser en vriend, opgedra. 


\section{Inleiding}

Christologie vorm die sentrum van die Johanneïese teologiese nadenke. Jesus is nie alleen die protagonis in die narratief nie, maar word veelkleurig met verskillende titels en beskrywings benoem, onder andere die Seun (van God en die mens), die geïnkarneerde Logos, die Messias, die koning van Israel (die Jode), die profeet, die opstanding en die lewe, die goeie herder, die waarheid, die lig, die ware wingerdstok, en so meer, almal beskrywings wat die rykdom van die Christologie belig. 'n Beskrywing wat egter relatief minder aandag in besprekings ontvang, maar tog 'n sentrale rol in die Christologiese beskrywing speel, is die konsep van 'leermeester' of 'onderwyser' (ó $\delta ı \delta a ́ \sigma \kappa a \lambda o \varsigma)$. Die aktiwiteit van onderrig word as konsep met verskillende $(\mathrm{P})$ persone in die Evangelie verbind en dra op verskillende wyses tot die geheelboodskap by. Die Johanneïese teologiese struktuur word tot so mate deur die konsep van opvoeding bepaal dat as die aspek (hipoteties) uit die struktuur gehaal sou word, verloor die teologiese struktuur sy sinvolle samehang.

In hierdie artikel gaan die konsep van 'onderrig' in die Evangelie as sleutelkonsep belig word aan die hand van vrae oor die gebruik van verskillende terme, die konsepsuele metaforiese beskrywings wat aangewend word en die doel met die gebruik en aanwending van die konsep, belig word.

Leksikografies word in die Evangelie van Johannes veral die woord $\delta$ เ $\delta \dot{\sigma} \sigma \kappa-$ en derivate (beide die werkwoord en selfstandige naamwoorde) in die betekenis van onderrig of leermeester gebruik. Enkele ander woorde soos $\hat{\rho} \alpha \beta \beta \dot{i}, \gamma \rho \dot{\alpha} \mu \mu \alpha \tau \alpha$ en $\mu \alpha \theta-{ }_{-}{ }^{2}$ word ook teen 'n veel laer frekwensie gebruik. ${ }^{3}$

\section{a) Die gebruik van $\rho \alpha \beta \beta i, \rho \alpha \beta \beta o v v i$ of $\delta$ เ $\delta$ á $\sigma \kappa \alpha \lambda o \varsigma$}

Die Griekse selfstandige naamwoord $\delta\left\llcorner\delta a ́ \sigma \kappa \alpha \lambda\right.$ o wat as leraar/leermeester ${ }^{4}$ vertaal kan word en die ekwivalente Hebreeuse term ( $\dot{\rho} \alpha \beta \beta i$, $\rho \alpha \beta \beta o v v i)$ wat

2 Binne die woordgroep val verwysings na die dissipels ( $\mu a \theta \eta \tau \eta \dot{\varsigma})$. Aangesien dit 'n tema op sy eie is, gaan daar nie in hierdie artikel daaraan aandag gegee word nie.

3 Ander woorde wat na onderrig verwys is byvoorbeeld $\delta$ เ $\delta \alpha \kappa \tau$ oì $(6: 45$ - mense wat geleer

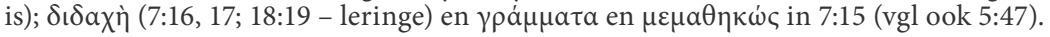

4 Die term vertaal moeilik in Afrikaans. Leraar of leermeester, wat algemeen in Afrikaanse vertalings gebruik word (ook nog in die nuutste 2014 vertaling), klink 
in die Evangelie getranskribeer word, kom telkens in die Evangelie voor. ${ }^{5}$ In twee gevalle word die Hebreeuse term (1:38 - $\rho \alpha \beta \beta i$ en 20:16 - $\rho \alpha \beta \beta o v v i ́)$

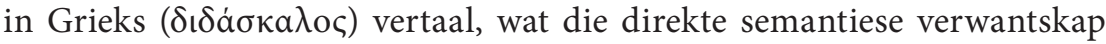
tussen die twee woorde aandui (Foulkes 1996:996).

\section{i) Allereers gaan die gebruik van die Hebreeuse woord $\rho \alpha \beta \beta i$ kortliks belig word.}

a) Opmerklik is dat die transkripsies van die Hebreeuse woorde alleen in die vokatief gebruik word ( $\rho \alpha \beta \beta i: 1: 38 ; 1: 49 ; 3: 2,26 ; 4: 31 ; 6: 25 ; 9: 2 ; 11: 8$; $\alpha \beta \beta \beta$ ovvi: $20: 16)$ en dus semanties as aanspreekvorm funksioneer. ${ }^{6}$ Die feit dat die Griekse woord $\delta\llcorner\delta a ́ \sigma \kappa a \lambda o \varsigma$ nie in die vokatief gebruik word nie, bevestig die gedagte dat as Jesus aangespreek word, Hy met die gebruik van die Hebreeuse term pertinent binne die Joodse religieus-kulturele raamwerk geplaas word.

b) Die titel of aanspreekvorm $\rho \alpha \beta \beta i$ word in die Evangelie nie eksklusief vir Jesus gebruik nie, maar in 3:26 word Johannes (die Doper) deur sy dissipels ook $\rho \alpha \beta \beta i$ genoem. Dit dui daarop dat die outeur met die titel nie 'n uitsonderlike funksie van Jesus wil beskryf nie, maar Jesus eerder funksioneel binne die algemene gebruik van die titel in die Joodse samelewing wil inbed. Köstenberger (1998:100-102) is daarom korrek as hy opmerk dat die term rabbi Jesus as 'Jewish religious teacher' wil identifiseer.

argaïes en word eintlik nie meer in alledaagse spraak gebruik nie. Na my mening werk dit beter in Nederlands, waar die vertalingsmoontlikheid nog algemeen in die samelewing gebruik word. Onderwyser is ' $n$ ander opsie, maar dek die betekenis van die Griekse woord nie heeltemal nie, soos uiteraard die woord leraar dit ook nie doen nie. Die Lewende vertaling se 'een van die geleerdes' is ook problematies omdat dit die funksie van onderrig wegvertaal. By gebrek aan 'n beter woord, gaan die woord leraar of leermeester in die artikel gebruik word, maar dan met die wete dat dit nie die Griekse en Hebreeuse terme semanties en funksioneel presies dek nie.

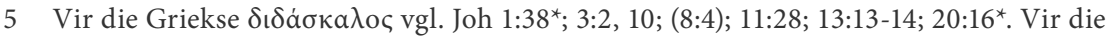
Hebreeuse $\dot{\rho} \alpha \beta \beta i /$ $\alpha \beta \beta$ ouví vgl. Joh $1: 38^{\star}, 49 ; 3: 2,26 ; 4: 31 ; 6: 25 ; 9: 2 ; 11: 8 ; 20: 16^{\star}$. In die verse wat met 'n sterretjie gemerk is, word gesê dat $\delta$ เ $\delta \dot{\alpha} \sigma \kappa \alpha \lambda$ oc die vertaling vir $\dot{\rho} \alpha \beta \beta i$ of $\rho \alpha \beta \beta o u v i$ is. Die vertaling word net een keer vir elk van die twee Hebreeuse woorde gegee. In die ander gevalle word dit sonder die vertaling gebruik. Die frekwensie van die gebruik van die Griekse en Hebreeuse woorde verskil nie noemenswaardig nie. Interessant genoeg word $\dot{\rho} \alpha \beta \beta \dot{i}$ net in die eerste deel van die Evangelie gebruik (eerste 12 hoofstukke), met die uitsondering van 20:16 ( $\dot{\alpha} \beta \beta$ ouvi). Dieselfde geld vir

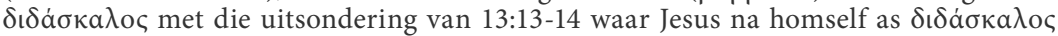
verwys en natuurlik die vertaling in 20:16 ( $\rho \alpha \beta \beta$ ovví).

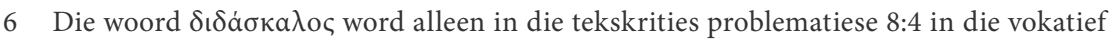
gebruik. 
Dit val ook op dat in van die kontekste waar Jesus as $\dot{\rho} \alpha \beta \beta i$ aangespreek word, die tekens wat Hy gedoen het, ook beklemtoon word. Nikodemus, wat hom in 3:2 as $\rho \alpha \beta \beta i$ aanspreek, bevestig dat niemand hierdie tekens kan doen as God nie met Hom is nie. In 6:25 is dit die skare wat Jesus $\alpha \beta \beta \hat{i}$ noem wat Jesus motiveer om na sy tekens te verwys. Nie alleen sy woorde nie, maar ook sy tekens het 'n openbarende funksie en is deel van sy lering as leermeester. Jesus leer dus ook deur sy voorbeeld, soos hy verder in 13:13-15 aan sy dissipels verduidelik.

Hengel (1981:42-45) argumenteer dat Jesus nie 'n rabbi in die Joodse sin van die woord was nie, met ander woorde, Hy staan buite die uniforme Joodse tradisie. ${ }^{7}$ Wat hy leer is in beginsel anders as die leringe van die Jode. As die term rabbi dus van Jesus gebruik word, is dit bloot uit respek. Hengel is natuurlik reg dat die onderrig van Jesus en die van die Joodse opponente verskil, hoewel daar ook natuurlik ooreenkomste is. Wat egter nie die geval is nie, is dat wat funksioneel van 'n Joodse rabbi sou geld nie van Jesus sou gegeld het nie. Die gebruik van die term rabbi dui nie op die inhoud van wat 'n persoon sê nie, maar op 'n funksie wat binne die Joodse samelewing uitgevoer word. By wyse van verduideliking: as twee professore op grond van verskillende opinies verskillende inhoude doseer, maak dit nie van die een meer van 'n professor as van die ander een nie en diskwalifiseer ook nie die een of die ander as professor nie. Die punt hier is dat Johannes Jesus funksioneel as rabbi binne die Joodse samelewing en verwagtingsraamwerk wil skets. Daarom gebruik hy hierdie term so dikwels (al het dit vertaling nodig) en as hoof aanspreekvorm (vokatief) as dit om Jesus as leermeester gaan. 'n Verdere argument ten gunste van bogenoemde opinie is die feit dat die Hebreeuse transkripsie ( $\dot{\rho} \alpha \beta \beta i)$ deurgaans as anspreekvorm in die Griekse teks gebruik word, dit terwyl die outeur die Griekse woord $\delta$ เ $\delta \dot{\sigma} \sigma \kappa \alpha \lambda$ o ken en dit eintlik vanselfsprekend is dat hy dit sou kon gebruik as hy wou. Hy kies egter vir die Hebreeuse titel om die Joodse referensie te behou.

c) 'n Verbandhoudende vraag is ook wie Jesus as $\dot{\rho} \alpha \beta \beta$ ' aanspreek. Soos te verwagte noem sy dissipels Hom $\dot{\rho} \alpha \beta \beta i$ (4:31; 9:2; 11:8). Tog is daar interessante nuanses in die gebruik van die woord. In twee gevalle noem

7 Hays (1996:138) se siening dat 'Jesus is represented in John not as a teacher...' stem nie ooreen met die gegewens uit die Evangelie nie. 
dissipels by hulle ontmoeting Jesus $\rho \alpha \beta \beta i(1: 38 ; 1: 49)$ voordat hulle werklik dissipels geword het. Dit beteken dat die term $\rho \alpha \beta \beta i$ nie alleen binne die nouer groep van die dissipels gebruik word nie, maar ook wyer deur mense wat nog nie deel van die intieme dissipelgroep is nie. Dit onderstreep dat Jesus binne 'n groter konteks as $\rho \alpha \beta \beta i$ erken word wat ook impliseer dat sy boodskap vir die groter gemeenskap bedoel is. Die gedagte word bevestig deur Nikodemus, 'n nagdissipel (3:2), wat as Joodse Fariseër Jesus by hulle eerste ontmoeting $\hat{\rho} \alpha \beta \beta i$ noem. Dan is daar ook Maria, wat wel met die Jesus-groep geassosieer word, maar nie strenggesproke een van die Twaalf was nie en Jesus in 20:16 $\rho \alpha \beta \beta i$ noem. Jesus se dissipels word ook nie net tot die Twaalf beperk nie (vgl. 6:61, 66). Uit hierdie gegewens blyk dat die outeur nie die gebruik van die woord $\dot{\rho} \alpha \beta \beta i$ tot die noue kring van die Twaalf wou beperk nie, maar die term as algemene sosiaal-funksionele term gebruik wat in die algemeen 'n spesifieke tipe persoon in die Joodse religieus-kulturele omgewing benoem het. Jesus word as Joodse rabbi binne die Joodse gemeenskap geplaas.

ii) Die gebruik van die woord $\delta \iota \delta \alpha ́ \sigma \kappa \alpha \lambda$ o word nou oorweeg

Soos reeds vermeld word die Griekse woord $\delta\llcorner\delta a ́ \sigma \kappa a \lambda$ oৎ nie in die vokatief gebruik nie (met uitsondering van die tekskrities problematiese teks in $8: 4)$. Met uitsondering van die twee gevalle waar die woord gebruik word om $\rho \alpha \beta \beta i / \rho \alpha \beta \beta$ ouví te vertaal $(1: 38 ; 20: 16)$ word dit semanties deurgaans as funksionele beskrywing gebruik, naamlik, iemand word 'n leermeester genoem vanweë wat hy sê, weet of doen (van Jesus: 3:2; 11:28; 13:13-14; van Nikodemus: 3:10). Maria verwys twee maal na Jesus as leermeester (11:28; 20:16), Nikodemus een maal (3:2), terwyl Jesus self sê dat sy dissipels hom leermeester noem (13:13-14). In hierdie kontekste speel die woord $\rho \alpha \beta \beta \dot{i}$ ook 'n rol wat die bedoelde oorvleueling tussen die twee woorde, $\rho \alpha \beta \beta i$ en $\delta\llcorner\delta \dot{\alpha} \sigma \kappa \alpha \lambda$ os onderstreep. Byvoorbeeld, nêrens in die Evangelie noem die Twaalf Jesus $\delta ı \delta \dot{\sigma} \sigma \kappa a \lambda o \varsigma$ (soos 13:13-14 beweer) nie, maar wel $\rho \alpha \beta \beta i ́$. Weereens word die gebruik van die woord nie eksklusief tot Jesus alleen beperk nie, maar sluit Nikodemus ook in, wat soos in die geval van die gebruik van $\rho \alpha \beta \beta i$ op 'n meer algemene gebruik dui. Met die gebruik van

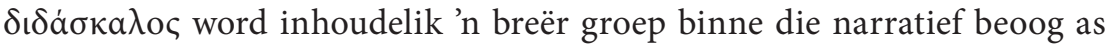
bloot die dissipelkring van Jesus. 
Die gebruik van die woorde, soos hierbo beskryf, is te spesifiek om toevallig of sonder betekenis te wees. Dat die Hebreeuse woord $\rho \alpha \beta \beta i$ Jesus as Joodse leraar wil tipeer, of dat die woord $\delta$ เ $\delta$ á $\alpha a \lambda$ o die funksie van Jesus as iemand wat die volk leer wil aandui, is reeds hierbo beredeneer. Die funksie van 'n Joodse leraar in 'n algemeen Joodse onderrigsituasie word as raamwerk vir Jesus se onderrigaktiwiteite gesuggereer. Dit maak 'n onmiskenbare deel van die oppervlaktestruktuur van die narratief uit. Dat dit die geval was, word ook ondersteun deur ander verwysings na onderrig. As die Jode byvoorbeeld na die onderrig van Jesus verwys, doen

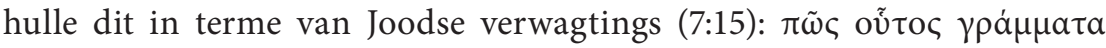

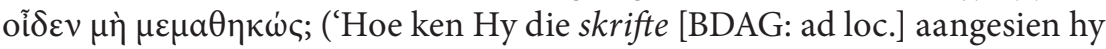
nie gestudeer het nie?). ${ }^{8}$ In 5:47 word na Moses se geskrifte verwys as toĩ

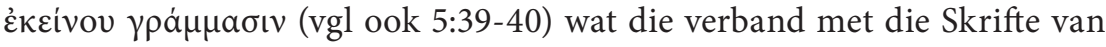
Israel lê.

Beide Jesus en Johannes (die Doper) het dissipels (oi $\left.\mu a \theta \eta \tau \alpha i^{9}\right)$ gehad wat die bekende Joodse situasie van 'n $\rho \alpha \beta \beta i$ met leerlinge wat deur hulle leermeester onderrig word, suggereer. Hoe het so tipiese Joodse onderrig daar uitgesien? Dit kan (vanweë beperkinge in ruimte) nie volledig hier uiteengesit word nie, maar 'n kort beskrywing op 'n hoër vlak van abstraksie is tog ter agtergrond nodig. Soos te verwagte, het die dissipels hulle leermeester gevolg en van hom geleer deur noukeurig op sy woorde en dade te let (Köstenberger 1998:119 gee die volgende verwysings ter ondersteuning: $b$. Ber. 23a, b, 24a, 60a, b. Šabb. 12b, 108b, 112a; b. cErub. 30a; b. Roš Haš.34b; y. Hag. 2:1; y. B. Mes. 2:3). ${ }^{10}$ Die verhouding is deur 'n openheid gekarakteriseer, soos Aberbach (1946:101) opmerk: 'In spite of the extraordinary reverence in which rabbis were held by their students, the relations between them were usually very close and far from formal. It

8 Die opmerking val tog enigsins snaaks op die oor, aangesien dit volgens die Evangelie van Johannes lyk of Jesus moontlik 'n dissipel van Johannes (die Doper) was. Tog word dit in die volgende verse reggestel, waar Jesus op sy onderrig deur die Vader wys. Hy is deur die Vader onderrig en nie deur mense nie.

9 BDAG (ad loc.) beskryf die leksikografiese betekenis so: 'one who engages in learning through instruction from another, pupil, apprentice;... one who is rather constantly associated with someone who has a pedagogical reputation or a particular set of views, disciple, adherent'.

10 Die verwysings na rabbynse literatuur veronderstel dat dit om 'n algemene voortsetting van tradisie gaan wat in later literatuur geëggo word. 
was...essentially a paternal-filial relationship transcended and surpassed by the intense love master and disciple bore to each other (Cant. Rab. 8:7; b. Ber. 5b; b. Sanh. 101a)'. Köstenberger (1998:122) vergelyk die verhouding tussen die leermeester en sy dissipels met die verhouding binne 'n gesin, hoewel laasgenoemde op natuurlike verwantskap berus en eersgenoemde op keuse. Binne die verhouding was daar verwagtings en het die verskillende lede spesifieke verantwoordelikhede binne die groep gehad. Onderling moes hulle sorg vir die groep se goeie funksionering, wat natuurlik tot 'n differensiasie van take aanleiding gegee het.

Tipies van die Joodse onderrigsituasie was die dissipels ook vry om vrae te vra as hulle iets nie verstaan het nie en kon selfs met die leermeester oor sake argumenteer. In die verband noem Aberbach (1946:94): 'Students would not hesitate to question their teacher when his actions seemed to contradict his teachings or when his behaviour appeared unseemly (cf. m. Ber. 2:6-7; y. Sot. 1:4)'. 'n Uitgangspunt was dat 'a shame-faced person cannot learn' ( $m$. 'Abot 2:5). Die gesprekke het gewoonlik plaasgevind as die rabbi met sy dissipels alleen was sodat die leermeester nie in verleentheid kom nie (in lyn met die antieke 'honor-shame' gebruike). 'n Dissipel was ook nie veronderstel om irrelevante vrae te stel nie, want dit kon ook die leermeester in verleentheid bring. Dit was 'n kenmerk van die wyse persoon om relevante vrae te vra, terwyl die ongekultureerde Golem die teenoorgestelde sou doen (Aberbach 1946:95-99 - ter ondersteuning verwys hy na die volgende $b$. Shab. 3b; $m$. 'Abot 5:7; Der. Er. Zut. 1). Die doel van die onderrig was om die dissipels voor te berei om die onderrig verder te neem en self leermeesters te word, soos Gerhardsson (1961:185) aandui: 'the Rabbi's didactic symbolic actions...concrete, visible measures whereby they capture the attention of their pupils, after which they either explain what they have done or leave it to the pupils to work it but for themselves'. Die perfekte dissipel was die dissipel wat 'fully absorbed his master's teaching' en 'was drawing on it to spread it abroad' (b. Yoma 28a).

Uit bogenoemde kort uiteensetting is die parallelle met dit beskrywing van Jesus en sy dissipels in die Evangelie van Johannes onmiskenbaar. Die paßßí Jesus word deur sy dissipels nagevolg $(1: 39,43)$, hulle vorm 'n lojale groep wat bereid is om hulle $\rho \alpha \beta \beta i$ tot die dood te volg $(11: 16 ; 13: 36-38)$. Die groep is goed georganiseer met die oog op selfonderhouding; Hulle het verdedigers (met die swaard - 18:10) en lede wat vir die toeganklikheid van 
hulle $\rho \alpha \beta \beta$ i sorg (12:20-21), het 'n beursdraer (13:29), het lede wat vir die kos sorg (6:5; vgl. ook 4:8) en eet as geliefdes in 'n noue kring saam (13-16) en moet die opdragte van hulle Leermeester gehoorsaam (13:34-35). Tipies van dissipelskap luister hulle na wat hulle $\rho \alpha \beta \beta i$ leer en vra Hom uit oor wat Hy gesê het $(9: 2-4 ; 14: 6-10)$. Hulle argumenteer selfs met Jesus as wat Hy sê of doen nie duidelik is nie (vgl. Petrus - 13:6-10, 36-38; die dissipels 11:5-16).

Bogenoemde gegewens dui daarop dat die Evangelie Jesus en sy dissipels binne die tipiese Joodse wyse van onderrig plaas van 'n leermeester met volgelinge wat onderrig word om dan self die boodskap verder te dra. Jesus word in die narratief inderdaad as 'n Joodse $\rho \alpha \beta \beta$ i wat sy dissipels leer, beskryf. ${ }^{11}$

Die werkwoord $\delta ı \delta \dot{\sigma} \kappa \omega$ word ook in die Evangelie gebruik - die vraag is of die gebruik van die werkwoord met die gebruik van die selfstandige naamwoorde ooreenstem?

\section{b. Die gebruik van die werkwoord $\delta$ เ $\delta$ á $\sigma \kappa \omega$}

Die gebruik van die werkwoord neem ons 'n stappie verder deur die inhoud van die lering van Jesus van nader te bepaal. ${ }^{12}$ Die konsep van onderrig word telkens in die Evangelie as funksionele aktiwiteit verduidelik. Byvoorbeeld, as Jesus die genesing van die lam man motiveer, beskryf Hy hoe die Vader hom 'leer' deur Hom alles te wys (5:17-23). In 'n ander geval bespiegel die mense oor waar Jesus aan sy 'teologiese' kennis kom, want Hy het nie formele opleiding gehad nie (7:15). As Jesus dan sy posisie as getuie van God verdedig, beroep Hy hom op sy onderrig deur sy Vader (8:28).

As daar in die Evangelie gesê word dat Jesus leer (werkwoord: $\delta\llcorner\delta a ́ \sigma \kappa \omega)$, word die onderrig in die tempel of sinagoge gelokaliseer $(6: 59 ; 7: 28 ; 8: 20$; 18:20). Dit beteken natuurlik dat Jesus se onderrig nie alleen vir sy dissipels

11 Aangesien die dissipelskap in die Evangelie van Johannes deeglik in die sekondêre literatuur beskryf is, word daar nie hier verder op ingegaan nie. Dit word egter binne die raamwerk van die tipies Joodse onderrig aangebied. Vgl. byvoorbeeld, Segovia (1985); Du Rand (1991); Tolmie (1995); Longenecker (1996); Van der Merwe (1997); Chennattu (2006); Farelly (2010).

12 Vir die werkwoord $\delta$ เ $\delta$ á $\kappa \omega$ vgl. 6:59; 7:28, 35; 8:20; 9:34; (teenswoordige tyd); 8:28; 18:19, 28 (aoristus); 14:26 (toekomstige tyd). 
bedoel is nie, maar as Joodse rabbi onderrig Hy die Jode binne hulle spesifieke godsdienstige ruimtes.

Die inhoud van sy onderrig word in verskillende teksdele in Johannes uiteenlopend beskryf:

1. In 6:59 gaan die onderrig van Jesus oor Hom as die Brood van die lewe en dus die simboliese eet van sy liggaam en die drink van sy bloed (eet $=$ geloof in Hom). Die teologiese fokus van die lering is op die funksie van Jesus as die Een in wie geglo moet word ten einde die eskatologiese lewe te ontvang. Dit raak die kern van sy boodskap (20:30-31).

2. 'n Verwysing na Jesus se onderrig word in 7:28 te midde van die konflik tussen Jesus en die Joodse opponente oor die interpretasie van die Wet gemaak. Hierdie is inderdaad die kerngedeelte in die Evangelie waar die houding van Jesus teenoor die Wet beskryf word.

3. 'n 'Aside' of vertellersopmerking word in 8:20 oor Jesus se onderrig gemaak te midde van Jesus se argument met sy Joodse opponente oor sy identiteit en geskiktheid om oor die waarheid te getuig. Die onvermoë van Jesus se opponente om Jesus te herken vir wie Hy is, ten spyte van sy leer en optrede, dien as bewys van hulle gebrek aan kennis van God, die God wat hulle bely as hulle God (8:54).

4. In sy verdediging voor die Hoëpriester noem Jesus dat hy openlik en in die publieke godsdienstige ruimtes, naamlik die tempel en sinagoges onderrig het (18:20). Vanuit antieke perspektief beteken dit dat Hy geen geheime het nie en ook nie iets wou wegsteek nie, wat natuurlik die eerlikheid en opregtheid van sy boodskap waarborg. Sy boodskap is inderdaad vir almal bedoel.

Uit hierdie kort oorsig is dit duidelik dat as dit om die onderrig van Jesus in die Evangelie gaan, dit nie tot een aspek beperk is nie, maar dat dit alles wat Jesus gepredik het insluit (veral in die Joodse religieuse ruimtes van die tempel en sinagoge), onder andere sy soteriologiese funksie, sy identiteit en sy houding teenoor die Joodse tradisie.

Dat sy lering in die Evangelie 'n generiese karakter dra, word deur die gebruik van die term in 7:35 bevestig, waar die Jode op Jesus se woorde dat 
Hy weer weggaan, reageer. Hulle wonder waarheen Hy gaan en bespiegel of Hy dalk die Grieke elders gaan 'leer'. Hier verwys die woord onderrig nie na een aspek van Jesus se leer nie, maar na die boodskap van Jesus as geheel.

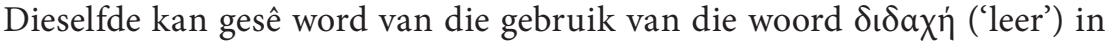
18:19. Jesus word deur die Hoëpriester oor sy 'leer' uitgevra om sodoende tydens die verhoor inligting in te samel oor wat Jesus alles gepreek het. Ook hier vind ons 'n generiese gebruik van die woord. Dieselfde geld ook vir 7:16-17 waar Jesus na sy leer wat van God af kom, verwys. Die Evangelie werk dus deeglik met die oorkoepelende konsep van die 'leer' van Jesus. Dit dui op 'n 'leer' wat bekend was (18:19), veral onder die gelowiges en wat in die Evangelie weerspieël word (vgl. ook 20:30-31).

In enkele ander gevalle word die $\delta$ เ $\delta \dot{\sigma} \sigma \kappa-w o o r d g r o e p ~ o o k ~ g e b r u i k$, hoewel nie van Jesus direk nie. In die konteks van 9:34 word oor die debat (strydgesprek) tussen die Joodse leiers en die geneesde blinde man berig. Die blinde man tree as (teologiese) oorwinnaar uit die stryd (9:2434) waarop die Joodse opponente hom beskuldig dat hy volledig in sonde gebore is en dan wil hy hulle (as die outoritatiewe religieuse leiers wat

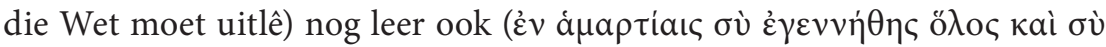

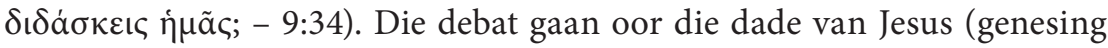
van die blinde) wat Hy alleen kan doen as God aan sy kant is - dus word Jesus se dade in die lig van teologiese voorveronderstellings (dat alleen God lewe kan gee) geïnterpreteer. Die 'teologiese' interpretasie van die geneesde blinde man word deur die Joodse opponente as 'lering' deur 'n 'dissipel' van Jesus beskryf $(9: 28,34)$, wat die semantiese aard van die woord help bepaal. Dit gaan oor informasie met die goddelike, religieuse, transendente inhoud. Die verwysing na dissipelskap in die konteks plaas die lering binne 'n Joodse onderrigraamwerk.

Twee verdere gebruike van $\delta$ เ $\delta \dot{\sigma} \sigma \kappa \omega$ in 8:28 (die Vader leer Jesus) en 14:26 (die Parakleet leer die gelowiges [dissipels]) gaan later op teruggekom word.

Die werkwoord $\delta เ \delta a ́ \sigma \kappa \omega$ funksioneer dus ook soos die selfstandige naamwoorde binne'n Joodse onderrigraamwerk en verwys na die aktiwiteit van Jesus se onderrig in die algemeen. Dit is egter nie die volledige prentjie nie. 


\section{Jesus word geleer...}

Soos hierbo aangetoon, word Jesus in die Evangelie met noemenswaardige frekwensie as 'n leermeester beskryf. Verwysings na onderrig in die Evangelie is egter nie beperk tot die kontekste waar die terminologie, wat hierbo bespreek is, voorkom nie, maar word in die Evangelie konsepsueel en metafories baie breër as bloot die terminologiese voorkomste ontwikkel.

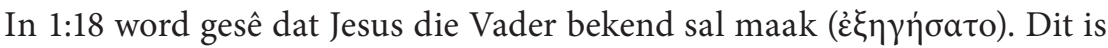
moontlik op grond die intieme verhouding wat tussen die Vader en Seun bestaan. Die intieme verhouding, wat onder andere by wyse van familiale metafore beskryf word (Vader, Seun - Van der Watt 2000), vorm die basis van onder andere die metaforiese beskrywing van die onderrig van die Seun deur die Vader. Ten einde die onderrigmetafoor te interpreteer moet die sosiaal-konsepsuele raamwerk van antieke onderrig op die vlak van familie-onderrig kortliks belig word.

In die antieke Mediterreense wêreld was die opvoeding van kinders sentraal belangrik, hoewel daar nie 'n enkele oorkoepelende onderwyssisteem was nie. Vir ons doeleindes kan daar veral tussen twee breë benaderings onderskei word - die situasie was natuurlik baie meer gevarieerd en die twee benaderings kon ook oorvleuel. Vir die punt wat hier gemaak wil word, is hierdie fyner detail nie van belang nie.

Die een benadering was deel van die Grieks-Romeinse kulturele tradisie, wat natuurlik in die Hellenistiese tyd oor die hele Romeinse Ryk bekend was. Dit was 'n meer formele onderrigsisteem waarbinne kinders, wie se ouers dit kon bekostig, deur 'onderwysers' of pedagoë onderrig is en het vakke soos retoriek, musiek, grammatika en so meer ingesluit. ${ }^{13}$ Mimesis het 'n belangrike rol gespeel (Hunter 2012:20), soveel so dat die leerling die styl van die onderwyser moes aanleer 'to the degree that in some cases the student and teacher could exchange places' (Eastman 2008:432-433). Shelton (1988:104 - vgl. ook Plutarchus Die lewe van Marcus Cato XX.47; Takitus Dial. Or. 28-29) beklemtoon egter dat die vader selfs onder die Romeine vir die opvoeding van hulle seuns verantwoordelik gehou is.

13 Plutarchus Moralia 8f.; Dionysius of Halicarnassus Antiquitates Romanae XX.13, 3; Quintilianus (Institutio Oratoria I.iii.13-14); Josefus Ant. IV.260-264; Filo De Spec. Leg. II.236, 240-241. Dixon (1991:118). 
Hoewel hy sy verantwoordelikhede kon delegeer het hy primêr vir hulle opvoeding verantwoordelik gebly. Kurz (1985:107) merk in die verband op: 'The father was responsible for the total educaton of his children in the "way" that leads to a long, happy life' (vgl. ook Malherbe 2004:315).

Die ander sisteem, waar die Joodse bevolking ook deel aan gehad het, was 'tuisonderrig' ${ }^{14}$ waarvoor die ouers - vir seuns veral die vaders (vgl. Shelton 1988:13) - verantwoordelik was..$^{15}$ Die etos van 'n gesin, wat die tradisies, gewoontes en morele waardes van 'n gesin ingesluit het, was deur die vaders aan die kinders oorgedra (vgl. Tos. Qid. I, 11b; Neyrey 1996:120). Die etos was gesien as iets wat gerespekteer, nagestreef en gehoorsaam moes word (1 Makk 1,54-58; 2,15-28; 4,36-43; Josefus Ant. 1.3.1 \$72). Josefus (Ad Apion 2.204) beskryf die soberheid waarmee die proses moes plaasvind: "Dit gee ook aan ons die opdrag om daardie kinders op te voed in geleerdheid en om hulle in die wette te oefen, en om hulle bekend te stel aan die optrede van hulle voorgangers, sodat hulle hulle kan naboots...' (vgl. ook Ant. 1.2.3, 68-69; bQid 82ab).

In die Joodse samelewing het Tora-onderrig die vaderlike opvoedkundige bydraes aangevul, iets wat as baie belangrik vir die opvoeding beskou is (Ps 119,1; Gen 18,19; Deut 30,16; Spr 2,6). Die vader was ook verantwoordelik vir die vakkundige sowel as die morele vorming van sy seuns (vgl. Lemaire 1992:305-312). Kurz (1985:107) merk op dat 'the most common use for the image of fatherhood is the comparison of teaching activities to parental duties. It envisages not merely formal teaching but the total formation...' Die seun het van ongeveer sy sesde jaar af saam met sy vader gaan 'werk' en gevolglik geluister wat sy vader gesê en dopgehou wat sy vader gedoen het. Die onderrigpatrone het ook vereis dat dit wat gehoor is mondelings herhaal is sodat die boodskap goed gememoriseer kon word (Lemaire 1992:305312; Barrett 1978:259). So het hy van sy vader geleer - beide wat beroep en morele waardes betref. Filo (De Spec Leg II.236) het ook byvoorbeeld

14 By gebrek aan 'n beter woord word 'tuisonderrig' gebruik om die sisteem van opvoeding wat tuis deur die vader en natuurlik ook die breër familie gedoen is, aan te dui.

15 Hier word nie aan die 'natuurlike onderrig' van babas en kleuters aandag gegee nie. Plato (Wette 7.792e) beklemtoon dat op grond van die mag van die gewoonte moet onderrig reeds vanaf die geboorte begin, om sodoende die karakter van die kind die effektiefste te vorm (vgl. ook Dixon 1991:118). Hy het selfs voorgestel dat die swanger moeder rustig, vrolik en kalm moes bly omdat dit ook 'n effek op die baba kon hê. Die bespreking hierbo is alleen op groter kinders wat al onderrigbaar was, gemik. 
opgemerk dat geen vader sy seun sal onderrig op ' $n$ manier wat in stryd is met deugsaamheid nie. Van die kinders is natuurlik gehoorsaamheid verwag (McGrath 1998:472). Dit is gesien as een van die pilare van antieke opvoeding (Eks 20:12; Spr. 1:8; 4:1vv; 6:20; 23:22-25). Die tipiese goeie seun is die seun wat volgens die wil van sy vader optree. Seuns kon naas die 'tuisonderrig' ook 'verder studeer' deur byvoorbeeld by 'n rabbi as dissipel aan te sluit, soos hierbo aangetoon is.

Binne beide bogenoemde sisteme het die ouers 'n sentrale rol gespeel, ten minste wat die verantwoordelike om kinders te laat opvoed, betref (Spr. 1:8; 6:20; 23:22; Deut. 6:6-25. Vgl. ook 1 Kron. 4:14; Filo LA II:90; Griekse wêreld: Plato Krit 17:25; Romeinse wêreld: Plutarchus Marc. Cat. XX 4-7; Dixon 1991:118). Daar is ook gedifferensieer tussen seuns en dogters, en natuurlik het sosiale status en finansiële vermoëns ook verskillende opsies moontlik gemaak. ${ }^{16}$

In 5:19-23 word die onderrigsproses van Jesus metafories beskryf. Dit toon die tipiese eienskappe van 'tuisonderrig' wat eie was aan die Joodse styl van onderrig. ${ }^{17}$ Binne die familiale sosiale raamwerk van die liefde van 'n vader vir sy seun (5:19-20) word beskryf hoe die Vader die Seun alles

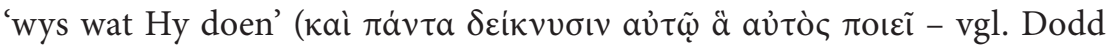
1968:30-40; Carson 1991:249). Dit vorm die opvoedkundige basis van 'tuisonderrig' - die vader dra sy vakkundige kennis aan die seun oor deur prakties te illustreer hoe dit gedoen word. Dit wat die Seun van die Vader leer word in 5:21 beskryf in terme van die gee van lewe (5:21); dit is die 'ambag' wat die Seun van die Vader geleer het - alleen God as skepper kan lewe gee. Daarmee saam het die Vader ook aan die Seun die mag en reg van die eskatologiese oordeel oorgedra (5:22). Die persoon wat oordeel het natuurlik in die antieke tyd morele mag besit en was in 'n sekere sin ook in beheer van die wet, aangesien die persoon die wette moes interpreteer en toepas. Barrett (1978:259) merk dus op: 'The activity of Jesus is not merely a reflection of an aspect of God's activity but a complete reflection, since the Father shows the Son all that he does'.

16 Hier word nie geïmpliseer dat net die Jode en geen ander volk hulle kinders so onderrig het nie, maar wel dat dit die wyse was waarop hulle hulle kinders onderrig het.

17 Vgl. 1 Sam 16:11; 2 Kon 4:18; Spr 1:8; 6:20; 23:22; 31:26; Deut 6:6-25; vgl. ook Tos. Qid. I, 11b; Filo, Alleg. Inter. II 90; Pos. Caini 181. 
Die klein werkwoordelike onderskeid tussen dit wat die Vader die Seun gewys het (om lewe te gee - 5:21), en dit wat Hy aan die Seun gegee het (oordeel - 5:22) kan dalk verklaar word in die lig van die sendingmotief wat in 5:23 deel van die proses gemaak word. Die Seun het nie alleen alles gesien wat die Vader doen nie, maar het ook die reg en vermoë ontvang om dit te doen, want as Gestuurde van die Vader moet Hy hierdie werk van Hom wat Jesus gestuur het, doen. Die Vader het nie alleen kennis aan die Seun gegee nie, maar ook die mag om goddelike aksies soos lewe gee of eskatologies te oordeel, uit te voer (Bühner 1977:245). As gestuurde sê en doen Hy alleen dit wat Hy gehoor en gesien het (3:32-33; 7:15-16). Die mag wat Jesus het, eggo ander uitsprake in die Evangelie waar daar gesê word dat die Vader alles in die hande van sy Seun gegee het (3:35).

Die onderrig van Jesus dien dus ook die doel om Hom in staat te stel om sy sending te volbring. Die onderrig van Jesus en sy sending word teologies geïntegreer. Veral in 8:28 verduidelik Jesus aan sy opponente dat wat Hy by die Vader geleer het, sy sending en die inhoud daarvan bepaal (vgl. ook $8: 26,38,40)$. Die argument oor onderrig tesame met die antieke familiale konvensie dat 'n kind doen wat sy vader doen (8:39), vorm die basis vir die identifikasie van Jesus as die een wat vir die waarheid getuig. Op grond van sy onderrig kan Hy doen wat God, die Vader, op aarde sou doen. So maak Hy die Vader op aarde teenwoordig deur die Vader se woorde te praat en sy werke te doen (14:9-10).

Dit bevestig Jesus as die Jode wonder waar Hy aan sy kennis kom, want Hy het nie formeel by ' $n$ geleerde gestudeer nie (7:15). ${ }^{18}$ Aangesien sosiale status en die eer van ' $n$ persoon afhanklik was van onder andere sy opleiding (Neyrey 1996:119), is die status en die vermoë van Jesus onder die soeklig geplaas. Neyrey (1996:120) merk op: 'young men were only as good as their teachers and those who formed them in the social values enshrined in their past culture'. Die woordgebruik veronderstel formele (Joodse) onderrig

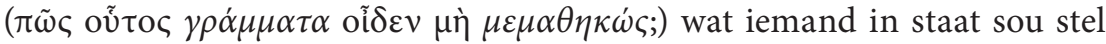

18 Eastman (2008:431) merk in die verband op dat 'education... functioned as a means of enculturation into a "system of hierarchical difference" that differentiated the educated from the uneducated by training young men (mainly) to be partners of the elite culture... to be educated was to distinguish oneself from those who were not and to secure one's identity on the "correct" side of the social polarities that structurerd Greco-Roman society'. Dit geld ook van die Joodse samelewing. Onderrig het 'n sosiale impak gehad deur leermeesters van leerlinge te onderskei. 
om die Tora te onderrig. Jesus se antwoord bring perspektief: wat Hy die mense leer ( $\dot{\eta} \dot{\varepsilon} \mu \grave{\eta} \delta$ เ $\delta \alpha \chi \grave{\eta})$ kom van God af wat Hom gestuur het. Hy het nie by gewone mense studeer nie, maar is direk deur God onderrig, wat dan veronderstel dat sy kennis dit sal inhou wat God aan Hom oorgedra het. Dit plaas die status en vermoë van Jesus in 'n totaal ander lig en konteks (5:23). Met daardie kennis en mag is Hy in staat om sy sending uit te voer. Die gedagte van onderrig, die uitvoering van God se wil en sending word hier weer in tandem vermeld.

In kort kan dus gesê word dat 'n tweede onderrigpatroon metafories in die Evangelie toegepas word. Die onderrig wat die vader aan sy seun gee dien as sosiale raamwerk vir die metaforiese toepassing op die Vader en Seun. Dit verteenwoordig 'n ander vorm van onderrig as die meer formele onderrig deur 'n rabbi aan sy dissipels.

\section{Jesus onderrig}

'n Primêre taak van Jesus is dus om te onderrig, nie alleen in woord nie, maar ook in daad. In die eerste gedeelte van die artikel, waar die konsep van onderrig aan die hand van woord $\delta\llcorner\delta a \dot{\sigma} \kappa-$ en derivate bespreek is, is Jesus as leraar asook sy onderrig reeds bespreek. Dit is dus nie nodig om hier weer in detail daarop in te gaan nie.

Kortom, daar is aangetoon dat as 'n mens vra na die inhoudelike leer

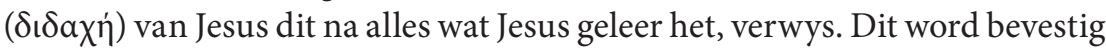
in Jesus se gesprek met die Hoëpriester (18:20-21) waar Jesus sê dat Hy in die openbaar in die tempel en sinagoges geleer het. In die narratief word daar telkens verwys na Jesus wat in die sinagoges of tempel (bv. 7:14, 28; $8: 20 ; 10: 23$; vgl. ook in die openbaar in Jerusalem - 5:2; sien ook 11:54) leer. Sy onderrig is nie alleen tot sy dissipels beperk nie, maar het die kosmos as geheel in die oog. Uit hierdie gedeeltes is dit duidelik dat Jesus se boodskap in sy geheel, soos dit in die Evangelie weergegee word, deel van die sy onderrig uitmaak. Wat sy wyse van leer betref word dit onder andere nie alleen by wyse van lang gesprekke of dia-(mono-)loë weergegee nie (vgl. byvoorbeeld 3:3-36; 13-16), maar ook deur strydgesprekke (bv. 7:16-24), privaat onderrig aan sy dissipels (bv. 4:31-38), of openbaringsgesprekke (11:20-27). Sy dade in die vorm van tekens $(2: 1-11 ; 5: 1-17$ ens.), illustratiewe optrede (13:1-17) en natuurlik sy dood (18-20) dien ook as onderrig (vgl. ook 10:17-18; 11:24-26). 


\section{Die Parakleet leer}

Ook die Parakleet is in die Evangelie vir onderrig verantwoordelik. ${ }^{19}$ Hays (1996:151) merk byvoorbeeld op: 'the Paraclete is to provide not only God's continuing presence within the community but also a source of continuing revelation' (vgl. Lingad 2001:226-227). Bennema (2007:116) verklaar die teenwoordigheid van die Gees so: 'However, by nature they are not able to do so, and further divine help is needed. What is needed is a cognitive agent "from above" who can assist people in thinking "from above" and consequently in accessing the realities "from above". This cognitive or epistemic divine agent is the Spirit'.

In Johannes14-16 berei Jesus sy dissipels op sy vertrek voor. In die konteks word die Gees beskryf as die een wat die gelowiges in die woorde van Jesus sal onderrig en lei: 'wanneer die Vader in my Naam die Voorspraak, die

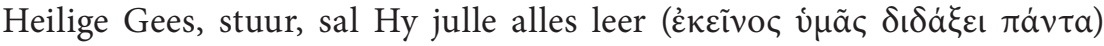
en julle herinner aan alles wat Ek vir julle gesê het' (14:26; vgl ook 16:1315). Binne die realiserende eskatologiese perspektief (vgl. van der Watt 2000) word die Parakleet beloof - Hy sal die dissipels (die volgelinge van Jesus) alles leer, meer spesifiek Hy sal hulle herinner aan die leer van Jesus



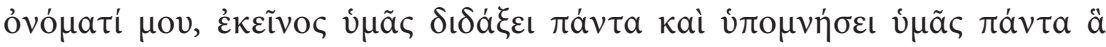

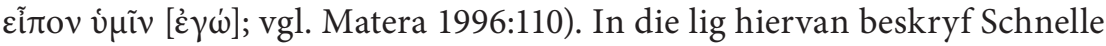
(1998:21) die funksie van die Gees-Parakleet so: 'Der Geist wird also keine neuen Offenbarungen über das Wirken Jesu hinaus bringen, sondern er vergegenwärtigt und erschließt die Jesus-Offenbarung. Hinter dieser Aussage stehen Erkenntnis-, Lehr-, und Lernprozesse der johanneischen Schule'. Die Gees-Parakleet funksioneer dus as fasiliteerder van Jesus se boodskap en dade. Daarmee saam sal Hy saam met die volgelinge van Jesus van Jesus getuig (15:26-27; vgl. ook 14:15-17). Die veronderstelling is dus dat die Heilige Gees (14:26), die Gees van die waarheid (15:26-27), in sy funksie as die Parakleet die tradisie asook die ontvouing van die tradisie sal fasiliteer. ${ }^{20}$ Dit suggereer 'n beweging van 'n persoonsgeoriënteerde na 'n tradisiegeoriënteerde gemeenskap.

19 Vgl. vir meer detail Bultmann (1978:485); Schnackenburg (1982:83); Schnelle (1998:20-21).

20 Schnelle (1998:19) beklemtoon die kontinuïteit van dit wat die Gees-Parakleet gaan doen: 'Der Paraklet ist bei der Gemeinde für "ewig", d.h. die Verbindung der 
Die Gees-Parakleet sorg dus vir die voortsetting van die goddelike onderrig van die gelowige volgelinge van Jesus. Die basis van hierdie onderrig is die onderrig wat Jesus gegee het deur sy woorde en dade.

Dit is op hierdie punt waar die rol van die 'Geliefde Dissipel' gewoonlik 'n belangrike rol speel (Charlesworth 1995; Bauckham 2007). Die aktiwiteite van die Gees-Parakleet en van die Geliefde Dissipel loop in 'n groot mate parallel, veral as dit by die oordrag van die tradisie kom. Opinies hieroor is meer as bekend in die Johanneïse navorsing en hoef daarom nie weer hier herhaal te word nie. Dit is genoeg om te beklemtoon dat dit Geliefde Dissipel, as die een wat die tradisie oordra, moontlik ook deur sommige as 'n verpersoonliking van die Gees-Parakleet gesien word. In die tradisiedraer, onder leiding van en verteenwoordigend van die Parakleet, word die onderrig voortgesit.

\section{Die dissipels leer nie - of leer hulle wel?}

Dit is interessant dat daar nie van die dissipels of volgelinge van Jesus gesê word dat hulle 'leer' nie, hoewel dit sekerlik 'n moontlikheid is, aangesien die term 'leer' wyer as net vir Jesus in die Evangelie gebruik word (9:34; vgl. ook $3: 10,26)$. Tog verkies die outeur om die term nie vir die aktiwiteite van die dissipels te gebruik of vir die voortsetting van die sending van Jesus deur sy volgelinge nie. Nogtans sit hulle as gestuurdes van Jesus die tradisie van Jesus voort, wat noodwendig die oordrag van die boodskap (lering?) moes ingesluit het. Hierbo is wel gesien dat hulle die sending van Jesus met behulp van die Heilige Gees voortsit (17:18; 20:21-22), wat hulle die draers van die tradisie in woord en daad maak (14:6-25).

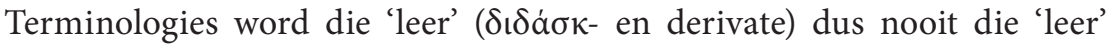
van die dissipels of gelowige volgelinge nie, maar bly die leer $(\delta\llcorner\delta a \chi \eta \dot{\eta})$ van Jesus waarvan hulle getuig. Die verkondiging van die dissipels word in terme van getuienis beskryf (15:27). Hulle getuig oor dit wat hulle geleer het. ${ }^{21}$ In 1 Johannes word die prentjie nog duideliker ontvou. Die dissipels

Glaubenden mit Jesus und durch Jesus mit Gott ist für alle Zukunft offen'.

21 Die woordgroep getuig ( $\mu \alpha \rho \tau \nu \rho-)$ word natuurlik op 'n verskeidenheid wyses vir verskeie akteurs en objekte in die Evangelie gebruik en is dus nie'n woord wat eksklusief van die dissipels geld nie. 
of volgelinge is getuies, nie onderwysers nie. Hulle getuig van wat hulle gesien en gehoor het (1 Johannes 1:1-4). Die Johanneïese groep staan ook vierkantig in die tradisie wat oorgelewer is, wat hulle gehoor het en wat hulle ken en weet (vgl. van der Watt 2013). Hulle is nou die draers en verteenwoordigers van die leer en daarom is hulle in die waarheid en leef hulle in die waarheid (21:24). Die onderrig van en oor Jesus gaan dus voort, maar nou as die getuienis van die dissipels.

\section{Enkele samevattende konklusies}

Binne die Evangelie van Johannes is onderrig die manier waarop transendente kennis van die Vader deur Jesus aan die wêreld bemiddel kan word. Die leer van Jesus, wat Hy van die Vader ontvang het, word die fokuspunt van ware kennis. Die volgelinge van Jesus kan alleen maar daarvan getuig met behulp van die Parakleet, die Gees van die waarheid. Die Parakleet is egter die fasiliteerder van die kennis van en oor Jesus en leer op sy beurt die volgelinge van Jesus verder deur hulle in die woorde van Jesus te onderrig en hulle daaraan te herinner. Daar is dus 'n duidelike ontwikkelende beweging van persoonlike onderrig deur 'n Persoon, Jesus, aan sy volgelinge na 'n gevestigde tradisie rakende die Persoon, Jesus waaroor daar alleen maar getuig kan word. Soos Jesus gestuur is, word die volgelinge van Jesus ook gestuur om van die woorde van Jesus te getuig. Binne die tradisie moet gebly word, omdat Jesus se woorde en dade binne die tradisie teenwoordig is en bly. Wie van die tradisie afwyk, distansieer hulle van die Johanneïese groep.

Die tema van onderrig vorm inderdaad 'n teologiese kernfaset van die Evangelie van Johannes. Indien Jesus nie geleer is nie, het Hy nie die woorde en dade van die Vader om te openbaar nie, is sy sending sonder inhoud, het Hy nie 'n soteriologiese boodskap nie, het sy dissipels ook geen boodskap om van te getuig nie en is die funksie van die Parakleet ook op die spel. Dit sou eintlik beteken dat die hele teologiese struktuur van die Evangelie in duie sou stort, wat die sentraliteit van die (metaforiese) konsep van onderrig in die Evangelie van Johannes onderstreep. 


\section{Bibliografie}

Aberbach, M 1967 Relations between master and disciple in the Talmudic age, in: Essays presented to chief rabbi Israel Brodie. (red.) Zimmels, HJ et al, London: Soncino, 2-26.

Arndt, W, Danker, FW en Bauer, W [BDAG] 2000 A Greek-English lexicon of the New Testament and other early Christian literature. Chicago: University of Chicago Press.

Barrett, CK 1978 The Gospel according to St John, London, SPCK.

Bauckham, R 2007 The testimony of the Beloved Disciple. Grand Rapids: Baker.

Bennema, C 2007 Christ, the Spirit and the knowledge of God: A study in Johannine

Epistemology, in: The Bible and epistemology: Biblical soundings on the knowledge of God, Healy, M en Parry, R (eds.), Milton Keys: Paternoster, 107-133.

Bühner, J-A 1977 Der Gesandte und sein Weg im 4. Evangelium, Tübingen; Mohr Siebeck.

Bultmann, R 1978 Das Evangelium des Johannes. Göttingen:Vandenhoeck \& Ruprecht.

Carson, DA 1991 The Gospel according to John. Leicester: IVP.

Charlesworth, JH 1995 The Beloved Disciple: whose witness validates the Gospel of John? London: Trinity Press International.

Chennattu, RM 2006 Johannine discipleship as a covenant relation. Peabody: Hendrickson.

Dixon, S 1991 The Roman Family. London: Hopkins.

Dodd, CH 1968 More New Testament Studies. Grand Rapids: Eerdmans.

Du Rand, JA 1991 'Perspectives on Johannine discipleship according to the Farewell Discourse', Neot. 25, 311-325. 
Eastman, S 2008 Imitating Christ imitating us: Paul's educational project in Philippians, in: The Word leaps the gap: Studies in Scripture and Theology in honor of Richard B. Hays. (ed.) Wagner, JR, Grieb, AK, Rowe, CK, Grand Rapids: Eerdmans, 427-451.

Farelly, N 2010 The disciples in the Fourth Gospel. Tübingen: Mohr Siebeck.

Gerhardsson, B 1961 Memory and Manuscript: Oral Tradition and Written Transmission in Rabbinic Judaism and Early Christianity. Uppsala: Gleerup.

Hays, RB 1996 The moral vision of the New Testament. A contemporary introduction to New Testament ethics. San Francisco: Harper.

Hengel, M 1981 The Charismatic leader and his followers. T\&T Clark: Edinburgh.

Hunter, R 2012 Plato and the traditions of ancient literature. Cambridge: Cambridge Univ Press.

Kurz, WS 1985 Kenotic imitation of Paul and of Christ in Philippians 2 and 3, in: Discipleship in the New Testament. (ed.) Segovia, FF, Philadelphia: Augsburg Fortress Press, 103-126.

Lemaire, A 1992 Education, in: Anchor Bible Dictionary. 301-317.

Lingad, CG 2001 The problems of Jewish Christians in the Johannine community. Rome.

Longenecker, RN (red.) 1996 Patterns of discipleship in the New Testament. Grand Rapids: Eerdmans.

Malherbe, AJ 2004 Paranesis in the Epistle of Titus, in: Early Christian paranesis in context. Starr, J en Engberg-Pedersen, T. Berlin: De Gruyter. 297-317.

Matera, F 1996 New Testament ethics: The legacies of Jesus and Paul. Louisville: Westminster John Knox.

McGrath, JF 1998 A rebellious son? Hugo Odeberg and the interpretation of John 5:18, NTS 44(3), 470-73. 
Neyrey, JH 1996 The trials (forensic) and tribulations (honor challenges) of Jesus: John 7 in Social Sciene Perspective, BTB 26 (3), 107-124.

Schnackenburg, R 1982 The Gospel according to St. John. Vol 3. London:Burns \& Oats.

Schnelle, U 1998 Johannes als Geisttheologie, NovTest 40(1), 17-31.

Segovia, F (red.) 1985 Discipleship in the New Testament. Philadelphia: Fortress.

Shelton, J-A 1988 As the Romans did. A source book in Roman social history. Oxford: OUP.

Tolmie, DF 1995 Jesus' farewell to the disciples: John 13:1-17:26 in narratological perspecitve. Leiden: Brill.

Van der Merwe, DG 1997 Towards a theological understanding of Johannine discipleship, Neot. 31, 339-359.

Van der Watt, JG 2000 Family of the King. Dynamics of metaphor in the Gospel according to John. Leiden: Brill.

Van der Watt JG 2013 Etiese besluitneming in 1 Johannes, Acta Theologica 33(2), 207-225. 